\title{
Thermostable phycocyanin from the red microalga Cyanidioschyzon merolae, a new natural blue food colorant
}

\author{
D. Y. Rahman ${ }^{1,2}$ - F. D. Sarian ${ }^{1}$ - A. van Wijk ${ }^{1}$ - M. Martinez-Garcia ${ }^{1}$. \\ M. J. E. C. van der Maarel $^{1}$
}

Received: 18 September 2016 / Revised and accepted: 1 November 2016/Published online: 21 November 2016

(C) The Author(s) 2016. This article is published with open access at Springerlink.com

\begin{abstract}
The demand for natural food colorants is growing as consumers question the use of artificial colorants more and more. The phycobiliprotein C-phycocyanin of Arthospira platensis is used as a natural blue colorant in certain food products. The thermoacidophilic red microalga Cyanidioschyzon merolae might provide an alternative source of phycocyanin. Cyanidioschyzon merolae belongs to the order Cyanidiophyceae of the phylum Rhodophyta. Its natural habitat are sulfuric hot springs and geysers found near volcanic areas in, e.g., Yellowstone National Park in the USA and in Java, Indonesia. It grows optimally at a $\mathrm{pH}$ between 0.5 and 3.0 and at temperatures up to $56^{\circ} \mathrm{C}$. The low pH at which $C$. merolae grows minimizes the risk of microbial contamination and could limit production loss. As C. merolae lacks a cell wall, phycocyanin with a high purity number of 9.9 could be extracted by an osmotic shock using a simple ultrapure water extraction followed by centrifugation. The denaturation midpoint at $\mathrm{pH} 5$ was $83^{\circ} \mathrm{C}$, being considerably higher than the $A$. platensis phycocyanin $\left(65^{\circ} \mathrm{C}\right)$. The $C$. merolae phycocyanin was relatively stable at $\mathrm{pH} 4$ and 5 up to $80^{\circ} \mathrm{C}$. The high thermostability at slightly acidic $\mathrm{pH}$ makes the C. merolae phycocyanin an interesting alternative to A. platensis phycocyanin as a natural blue food colorant.
\end{abstract}

M. J. E. C. van der Maarel

m.j.e.c.van.der.maarel@rug.nl

1 Aquatic Biotechnology and Bioproduct Engineering Department, Engineering and Technology Institute Groningen (ENTEG), University of Groningen, Nijenborgh 4, 9747 AG Groningen, The Netherlands

2 Research Center for Biotechnology, Indonesian Institute of Sciences (LIPI), Jl. Raya Bogor KM 46, 16911 Cibinong, Bogor, Indonesia
Keywords Food colorant $\cdot$ Phycocyanin $\cdot$ Pigments $\cdot$ Red microalga $\cdot$ Cyanidioschyzon merolae

\section{Introduction}

Synthetic dyes are used to provide color to all kinds of food products, confectionary, and beverages (Antello et al. 2008). Consumers have become suspicious about the use of these synthetic colorants as they are linked to having negative effect on children's behavior (McCann et al. 2007; Arnold et al. 2012). Several large retailers are following major food producers by banning food products containing artificial colorants from their stores. This leads to a growing demand for natural colorants derived from plants and algae. For most of the artificial colorants, natural alternatives are relatively easily available (Wrolstad and Culter 2012). More challenging is to find natural alternatives to the artificial blue colorants such as Patent Blue V (E131) or Brilliant Blue FCF (E133). Blue colors are widespread in nature but it turns out that it is difficult to replicate the blue color. At neutral $\mathrm{pH}$, natural blue colorants are stable but, especially at $\mathrm{pH}$ values below 5 , they are much less stable and fade quickly (Newsome et al. 2014). Recently the FDA and EFSA have given approval for use of a Spirulina (Arthrospira) platensis extract containing high levels of phycocyanin as natural blue food colorant for coloring candy and chewing gum (Code of Federal Regulation 2016). Besides the potential use as food colorant, phycocyanin has also been described as having interesting pharmaceutical and nutraceutical properties (Eriksen 2008).

Phycocyanin is a pigment-protein complex that is part of the phycobilisomes found in cyanobacteria and microalga. Phycobilisomes are large, water-soluble protein complexes attached to the cytoplasmic surface of the thylakoid membrane (Biggins and Bruce 1989) and serve as the major antenna 
complex harvesting light. Phycobilisomes can make up as much as $20 \%$ of the cellular protein content (Glazer 1989). Phycocyanin is an oligomeric protein composed of $\alpha$ and $\beta$ subunit to which several open chain tetrapyroles are attached (Stec et al. 1999; Padyana et al. 2001; Coyler et al. 2005). The tetrapyrole structures give the typical blue color to phycocyanin while the protein part confers the stability with respect to $\mathrm{pH}$ and temperature.

Arthrospira platensis phycocyanin has a limited thermostability as it denatures at temperatures above $60{ }^{\circ} \mathrm{C}$ (Jespersen et al. 2005; Martelli et al. 2014). In the search for a more thermostable and/or acid stable phycocyanin, the thermoacidophilic red microalga Cyanidioschyzon merolae was explored as a source of a blue colorant. Cyanidioschyzon merolae is a unicellular microalga belonging to the order Cyanidiophyceae of the phylum Rhodophyta. This species inhabits hot sulfuric springs and geysers in volcanic areas; it grows best at temperatures between 40 and $56{ }^{\circ} \mathrm{C}$ and acidic condition of $\mathrm{pH} 0.5$ to 3 (Ciniglia et al. 2004). The phycocyanin of another red microalga, Galdieria sulphuraria, has been investigated (Sloth et al. 2006; Sørensen et al. 2012) as this species not only grows at relatively high temperatures and low $\mathrm{pH}$, but also because it can grow heterotrophically in the dark on sugar as well as autotrophically in the light (Gross and Schnarrenberger 1995). Arthrospira platensis is grown outdoor in open ponds or raceway systems (Lee 1997; Belay 2013), suffering from productivity loss due to infection as it is difficult to maintain strict hygienic conditions (Richmond and Grobbelaar 1986). The extreme conditions applied to grow red microalga could be advantageous as infections are unlikely at the low $\mathrm{pH}$ levels applied. Sloth et al. (2006) and Sørensen et al. (2012) investigated the heterotrophic growth of $G$. sulphuraria on glucose in closed fermenters and found a reasonable phycocyanin productivity but concluded that the polysaccharide rich cell wall of $G$. sulphuraria makes it difficult to disrupt the cells and extract the phycocyanin. In addition, Sørensen et al. (2012) found that the phycocyanin extracted from $G$. sulphuraria cultures was not pure, as a considerable amount of protein and chlorophyll was also extracted. Cyanidioschyzon merolae could be a more effective source of phycocyanin as it lacks a cell wall (Lee 2004) making the extraction of the phycocyanin probably more efficient. This paper reports on the production and extraction of phycocyanin from $C$. merolae by a simple ultrapure water treatment.

\section{Materials and methods}

\section{Growth of $C$. merolae and phycocyanin extraction}

The red unicellular microalga Cyanidioschyzon merolae was obtained from National Institute for Environmental Studies (NIES, Japan), catalog no 1332. A stock culture was maintained in Allen medium pH 2 under constant light (100 $\mu \mathrm{mol}$ photons $\left.\mathrm{m}^{-2} \mathrm{~s}^{-1}\right)$ on a shaker at $150 \mathrm{rpm}$ and $40{ }^{\circ} \mathrm{C}$. Allen medium (Allen 1959) consisted of $1.32 \mathrm{~g} \mathrm{~L}^{-1}$ $\left(\mathrm{NH}_{4}\right)_{2} \mathrm{SO}_{4}, 0.27 \mathrm{~g} \mathrm{~L}^{-1} \mathrm{KH}_{2} \mathrm{PO}_{4}, 0.25 \mathrm{~g} \mathrm{~L}^{-1} \mathrm{MgSO}_{4} .7 \mathrm{H}_{2} \mathrm{O}$, $0.073 \mathrm{~g} \mathrm{~L}^{-1} \mathrm{CaCl}_{2} .2 \mathrm{H}_{2} \mathrm{O}, 11 \mathrm{mg} \mathrm{L}^{-1} \mathrm{FeCl}_{3}, 2.8 \mathrm{mg} \mathrm{L}^{-1}$ $\mathrm{H}_{3} \mathrm{BO}_{3}, 1.8 \mathrm{mg} \mathrm{L}^{-1} \mathrm{MnCl}_{2}, 0.218 \mathrm{mg} \mathrm{L}^{-1} \mathrm{ZnSO}_{4} .7 \mathrm{H}_{2} \mathrm{O}$, $0.05 \mathrm{mg} \mathrm{L}^{-1} \mathrm{CuSO}_{4}, 0.023 \mathrm{mg} \mathrm{L}^{-1} \mathrm{NH}_{4} \mathrm{VO}_{3}$, and $0.024 \mathrm{mg} \mathrm{L}^{-1} \mathrm{Na}_{2} \mathrm{MoO}_{4} \cdot 2 \mathrm{H}_{2} \mathrm{O}$. The $\mathrm{pH}$ of the medium was adjusted to 2.0 with $4 \mathrm{M} \mathrm{H}_{2} \mathrm{SO}_{4}$ and autoclaving at $120{ }^{\circ} \mathrm{C}$ for $20 \mathrm{~min}$. A 1-L photo-bioreactor (approximately $100 \mu \mathrm{mol}$ photons $\mathrm{m}^{-2} \mathrm{~s}^{-1}$ at $40{ }^{\circ} \mathrm{C}$ ) was used to grow C. merolae for phycocyanin production. Cultures were harvested by centrifugation at $10,000 \times g$ for $10 \mathrm{~min}$ at $4{ }^{\circ} \mathrm{C}$. The pellet was resuspended in ultrapure water, mixed well for $5 \mathrm{~min}$, and kept for several hours at room temperature. Cell debris was removed by centrifugation at $15,000 \times g$ at $4{ }^{\circ} \mathrm{C}$ for $15 \mathrm{~min}$; the blue colored supernatant was transferred to new tube for further analysis.

\section{Purification of phycocyanin}

To investigate the influence of the time of exposure to ultrapure water on the yield of phycocyanin, $200 \mathrm{mg}$ wet biomass were mixed well with 2-mL ultrapure water (Milli Q purification system) and left at room temperature for up to $300 \mathrm{~min}$. Blue colored supernatant was collected by centrifugation at $15,000 \times g$ and transferred into new tube. Besides mixing, two other extraction methods were used, bead beating by shaking the suspended cells with a small metal ball at high speed and high-pressure homogenization by means of implosion of the cells.

The crude phycocyanin extract obtained after mixing was further purified by ammonium sulfate precipitation in three steps $(20,40$, and $60 \%$ saturation). The precipitate was recovered by centrifugation at $10,000 \times g$ for $30 \mathrm{~min}$, the colorless supernatant was discarded, and the precipitate was dissolved in $50 \mathrm{mM}$ citrate buffer $\mathrm{pH} 5$ at room temperature.

\section{Determination of concentration}

The phycocyanin concentration was estimated by using a spectrophotometer, DR 3900 (Hach-Lange, The Netherlands). Measurement was conducted at 624 and 652, at which phycocyanin and allophycocyanin respectively show maximum absorption (Bennett and Bogorad 1973). The purity of phycocyanin was assessed by calculating the ratio of $A_{624}$ to $A_{280}$, where $A_{280}$ is the absorbance of total protein. The concentration phycocyanin was calculated using the following equation (Silveira et al. 2007):

Phycocyanin $\left(\mathrm{mg} \mathrm{mL}^{-1}\right)=\frac{\left(A_{624}-\left(A_{652} \times 0.474\right)\right.}{5.34}$ 


\section{Thermostability of phycocyanin}

To determine the denaturation midpoint, $1 \mathrm{~mL}$ of phycocyanin solution (initial OD $A_{620}=0.8$ ) was incubated at $\mathrm{pH} 5$ and different temperatures in a waterbath for $30 \mathrm{~min}$ (intervals of $10{ }^{\circ} \mathrm{C}$ from 30 to $100{ }^{\circ} \mathrm{C}$ ). The thermostability of the phycocyanin was measured by incubating samples at $\mathrm{pH} 5$ and $80{ }^{\circ} \mathrm{C}$ followed by measuring the absorbance at $624 \mathrm{~nm}$ at regular intervals $(0-150 \mathrm{~min})$. The remaining concentration of phycocyanin $\left(C_{\mathrm{R}}, \%\right)$ relative to the initial concentration was calculated using the following equation: $C_{\mathrm{R}}(\%)=$ $C / C_{0} \times 100$. To determine the $\mathrm{pH}$ stability of phycocyanin, the samples were incubated at $80{ }^{\circ} \mathrm{C}$ at different $\mathrm{pH}$ values from 2 to 5 , and the absorbance at $624 \mathrm{~nm}$ was measured at regular intervals (0 to $60 \mathrm{~min}$ ).

\section{Results and discussion}

\section{Growth of $C$. merolae and phycocyanin extraction}

The extremophilic red microalga C. merolae was grown autotrophically in mineral medium at $\mathrm{pH} 2$ and $40{ }^{\circ} \mathrm{C}$ with constant illumination (Fig. 1a). After about 3 days, it started to grow with a specific growth rate of $0.15 \pm 0.01$ day $^{-1}$. At day 21 , the cells had reached an $\mathrm{OD}_{800}$ of about 1.8 , which corresponds to a dry weight of $1.051 \pm 0.14 \mathrm{~g} \mathrm{~L}^{-1}$. An in vivo absorption spectrum (300 to $800 \mathrm{~nm}$ ) was made every day, showing that there were three main absorption maxima, at 430, 620, and $680 \mathrm{~nm}$ (Fig. 2). The 430 and $680 \mathrm{~nm}$ maxima are typical for chlorophyll (Giltelson et al. 1999), while the $620 \mathrm{~nm}$ maximum is typical for phycocyanin (Patel et al. 2005). The amount of phycocyanin per cell did not seem to

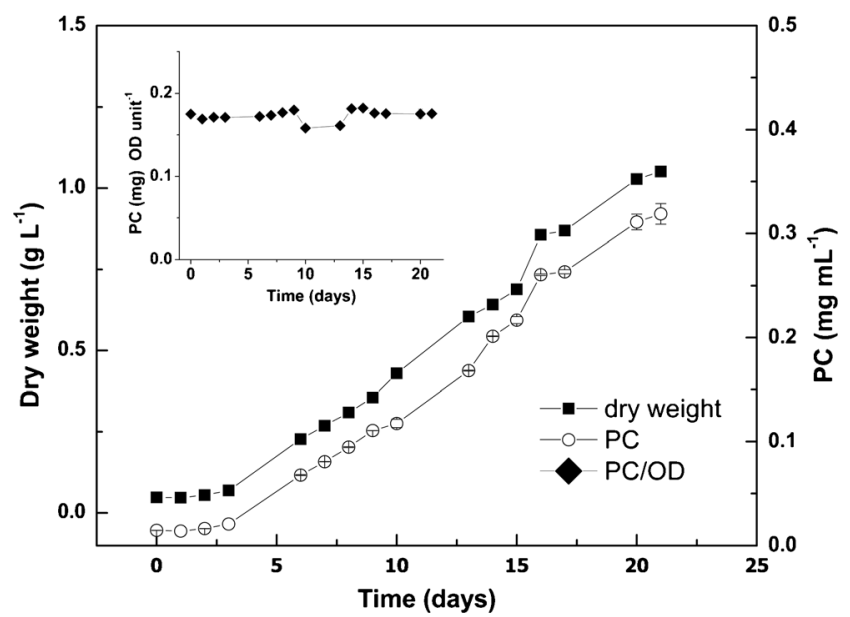

Fig. 1 Growth of C. merolae on air and light and the related phycocyanin production in vivo. (black squares), biomass, $\mathrm{g}$ dry weight $\mathrm{L}^{-1}$; (white circles) amount of in vivo phycocyanin measured at $620 \mathrm{~nm}$. In vivo phycocyanin amount per amount of biomass expressed as 1 unit of optical density at $800 \mathrm{~nm}$

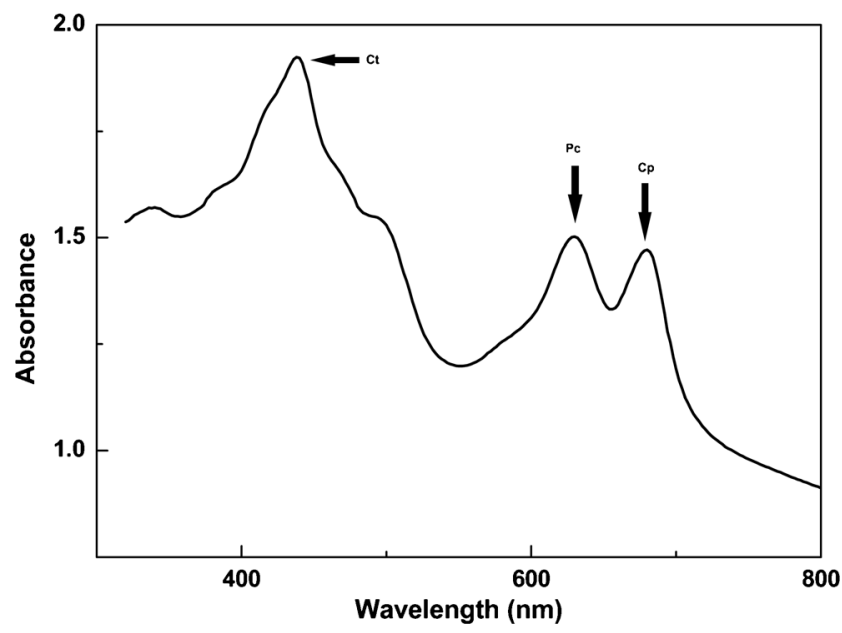

Fig. 2 In vivo VIS spectrum (300-800 nm) of C. merolae. The strong absorption peak at $680 \mathrm{~nm}$ is chlorophyll $(\mathrm{Cp})$, the absorption peak around $620 \mathrm{~nm}$ corresponds to phycocyanin $(\mathrm{Pc})$. Other absorption peaks in the range of $400-500 \mathrm{~nm}$ are from carotenoid $(\mathrm{Ct})$

vary as a constant value of about 17.5 to $18 \mathrm{mg}$ phycocyanin per unit of absorption at $800 \mathrm{~nm}$ was found for almost all time points (Fig. 1b).

To extract phycocyanin from the cells, several cell disruption methods were tested. Bead beating and high-pressure homogenization, both disruptive techniques, were compared with exposure of the cells to an osmotic shock by mixing them with ultrapure water (Fig. 3). The latter method worked best as most phycocyanin $\left(0.55 \mathrm{mg} \mathrm{mL}^{-1}\right)$ was found in solution. Cyanidioschyzon merolae is known to lack a cell wall (Albertano et al. 2000), making it susceptible to osmotic shocks. When exposed to ultrapure water, the cells take up water and finally lyse, releasing the cellular contents into the water. The water phase mainly contained phycocyanin $\left(A_{624}\right.$, Table 1$)$ with a purity index of 9.92 , calculated as the

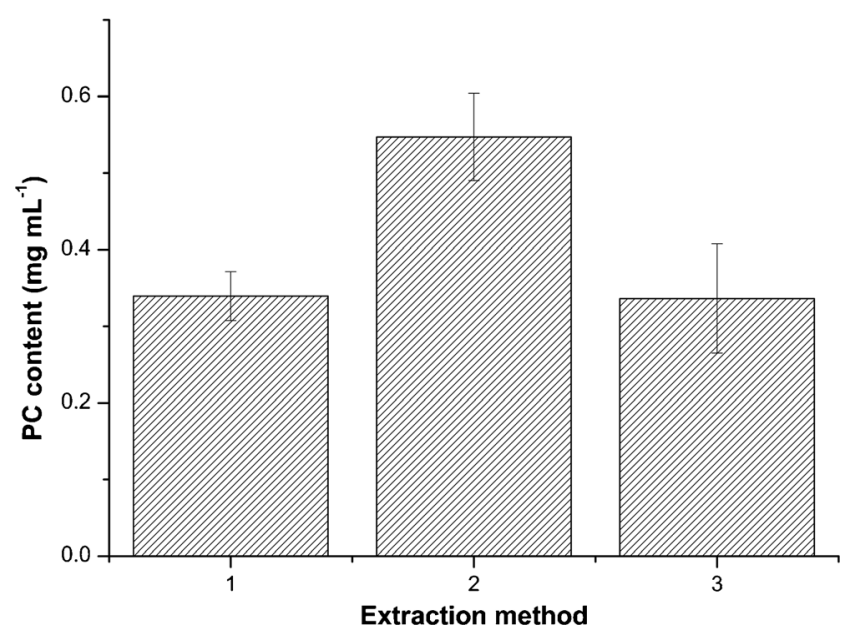

Fig. 3 Extraction yield of phycocyanin from C. merolae with different extraction methods, 1 : bead beater, 2 : mixing by vortex, and 3 : highpressure homogenizer 
ratio of $A_{624}$ to $A_{280}$ (protein). Small amounts of chlorophyll were also detected in the water phase $\left(A_{562}\right.$ and $A_{652}$, Table 1$)$.

\section{C. merolae phycocyanin extracted by osmotic shock has a high purity number}

The duration of the osmotic shock had a clear effect on the amount of phycocyanin extracted (Fig. 4). Incubating $C$. merolae cells in ultrapure water for up to $100 \mathrm{~min}$ gave relatively low amounts of phycocyanin in the water phase (up to $0.28 \mathrm{mg} \mathrm{mL}^{-1}$ ). However, a steep increase in the amount of phycocyanin was observed between 100 and 150 min incubation; after $150 \mathrm{~min}$, almost $0.81 \pm 0.09 \mathrm{mg} \mathrm{mL}^{-1}$ phycocyanin was released. Longer incubation did not result in a significant increase in the amount of phycocyanin released. The purity of the phycocyanin extract obtained with ultrapure water treatment is considerably higher than that of extracts obtained from Spirulina, with a purity index ranging from 0.46 to 2.78 (Silveira et al. 2007; Liao et al. 2011), from Synechococcus with a purity index of 2.2 (Gupta and Sainis 2010), and from the closely related red microalga G. sulphuraria of only 1 (Sørensen et al. 2012). The reason for the much higher purity index found for the phycocyanin extracted from C. merolae compared to other phototrophs is that the latter have a (thick) cell wall requiring a mechanical treatment to disrupt the cells and release the phycocyanin. As a result of the mechanical treatment of G. sulphuraria, also chlorophyll $a$ and carotenoids are released into solution (Sloth et al. 2006), resulting in much lower purity number for phycocyanin. Applying different purification techniques such as aqueous two phase extraction with polyethylene glycol and water (Rito-Palomares et al. 2004), ammonium sulfate precipitation of expended bed absorption in combination with chromatography resulted in higher purity numbers (Zhang and Chen 1999; Niu et al. 2007; Yan et al. 2011), but these are still considerably lower than the 9.9 found for $C$. merolae. Phycocyanin solution with a purity index of at least 0.7 are considered to be a food grade, while a purity index of at least 4 is considered to be analytical

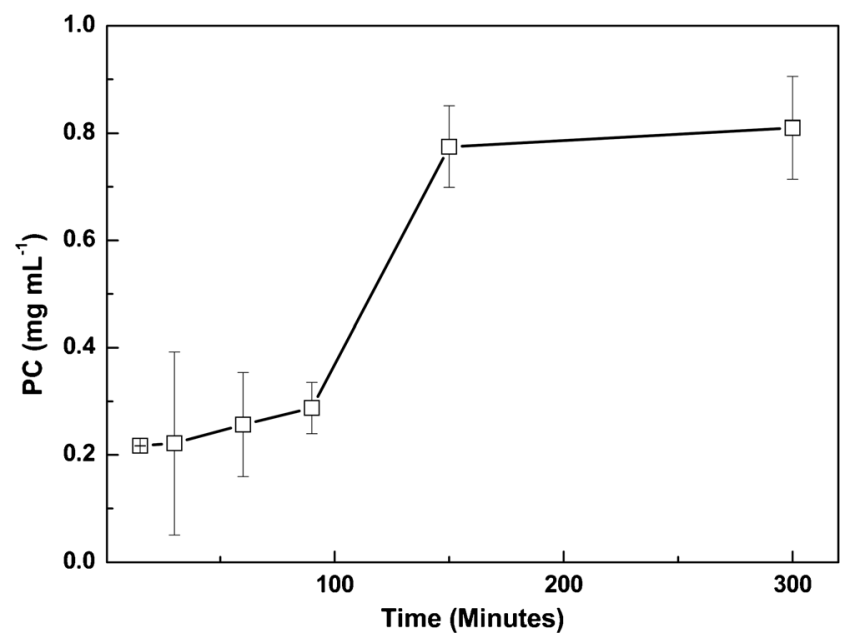

Fig. 4 The effect of exposing C. merolae cells to ultra pure water for an increasing amount of time (in $\mathrm{min}$ )

grade (Cisneros and Rito-Palomares 2004). The phycocyanin extracted from C. merolae grown cells has a high purity index any further purification is not required to use it as analytical grade material.

The ultrapure water extract containing phycocyanin was further purified by ammonium sulfate precipitation at $20-40 \%$ saturation resulting in a concentrated phycocyanin solution (54\% yield) with a purity index of 18.07 (Table 1). The pellet fraction $20-40 \%$ ammonium sulfate was dissolved in citrate buffer $(\mathrm{pH} 5)$ and was used to further characterize the C. merolae phycocyanin. The absorption spectrum of this fraction showed a clear $\lambda_{\max }$ at $624 \mathrm{~nm}$ (Fig. 5), being the phycocyanin, and shoulder at $562 \mathrm{~nm}$, indicative for phycoerythrin (Cisneros and Rito-Palomares 2004). The A. platensis phycocyanin has a $\lambda_{\max }$ of $616 \mathrm{~nm}$ at $\mathrm{pH} 5$ and 620 at $\mathrm{pH} 7$ (Jespersen et al. 2005). The thermophile Synechococcus lividus phycocyanin has $\lambda_{\max }$ of $609 \mathrm{~nm}$ at $\mathrm{pH} 6$ (Edwards et al. 1997), while Phormidium luridum phycocyanin has a $\lambda_{\max }$ at pH 6 of $622 \mathrm{~nm}$ (Edwards et al. 1996). Glazer and Fang (1996) even reported a $\lambda_{\max }$ of about $650 \mathrm{~nm}$ at pH 3 for the phycocyanin of Synechococcus sp.

Table 1 Absorption at different wavelengths of C. merolae crude extract and the different fraction of ammonium sulfate treated extract

\begin{tabular}{lllllll}
\hline & $\begin{array}{l}\text { Crude } \\
\text { extract }\end{array}$ & $\begin{array}{l}\text { Supernatant fraction } \\
\text { of } 20 \%\left(\mathrm{NH}_{4}\right)_{2} \mathrm{SO}_{4}\end{array}$ & $\begin{array}{l}\text { Supernatant fraction } \\
\text { of } 40 \%\left(\mathrm{NH}_{4}\right)_{2} \mathrm{SO}_{4}\end{array}$ & $\begin{array}{l}\text { Pellet fraction of } \\
40 \%\left(\mathrm{NH}_{4}\right)_{2} \mathrm{SO}_{4}\end{array}$ & $\begin{array}{l}\text { Supernatant fraction } \\
\text { of } 60 \%\left(\mathrm{NH}_{4}\right)_{2} \mathrm{SO}_{4}\end{array}$ & $\begin{array}{l}\text { Pellet fraction of } \\
60 \%\left(\mathrm{NH}_{4}\right)_{2} \mathrm{SO}_{4}\end{array}$ \\
\hline Volume of sample $(\mathrm{mL})$ & 40 & 40 & 40 & 10 & 40 & 10 \\
Dilution & $1: 5$ & $1: 5$ & $1: 5$ & $1: 20$ & $1: 5$ & $1: 20$ \\
$\mathrm{~A}_{652}$ & 0.098 & 0.096 & 0.032 & 0.059 & 0.019 & 0.031 \\
$\mathrm{~A}_{624}$ & 0.496 & 0.469 & 0.167 & 0.271 & 0.042 & 0.147 \\
$\mathrm{~A}_{562}$ & 0.145 & 0.135 & 0.049 & 0.135 & 0.017 & 0.048 \\
$\mathrm{~A}_{280}$ & 0.05 & 0.051 & 0.025 & 0.015 & 0.073 & 10.014 \\
Purity index & 9.92 & 9.26 & 6.78 & 18.07 & 0.58 & 1.2 \\
Total C-PC & 16.8 & 15.8 & 5.6 & 9.2 & 5.38 & 31.32 \\
Yield & 100 & 94.31 & 33.81 & 54.06 & & 7.38 \\
\hline
\end{tabular}




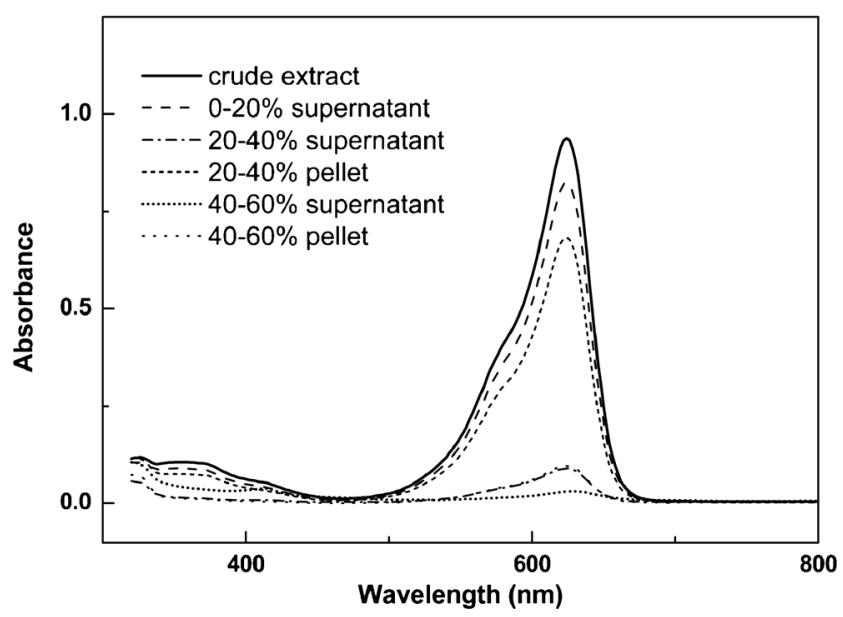

Fig. 5 Visible absorption spectra of soluble and precipitated phycocyanin from C. merolae at different ammonium sulfate concentrations

\section{C. merolae phycocyanin is thermostable}

The alpha and beta subunit of the phycocyanin having a molecular weight of 17-18 kDa were clearly visible on an SDS-
Table 2 Half-life of ammonium sulfate (40\% saturation) purified phycocyanin of $C$ merolae at room temperature $\left(22{ }^{\circ} \mathrm{C}\right)$ and $80{ }^{\circ} \mathrm{C}$ at pH 3, 4 and 5

\begin{tabular}{lcc}
\hline Temperature $\left({ }^{\circ} \mathrm{C}\right)$ & $\mathrm{pH}$ & Half-life $(\mathrm{min})$ \\
\hline 22 & 3 & $<5$ \\
& 4 & $>400$ \\
& 5 & $>1200$ \\
80 & 3 & $<5$ \\
& 4 & 29 \\
& 5 & 40 \\
\hline
\end{tabular}

polyacrylamide gel (data not shown). This is in agreement with the molecular weight of other phycocyanin reported so far (Glazer and Fang 1996; Chaiklahan et al. 2011). As $C$. merolae can grow at relatively high temperatures up to $55^{\circ} \mathrm{C}$, it is to be expected that the phycocyanin is relatively thermostable. The purified phycocyanin was incubated for $30 \mathrm{~min}$ in citrate buffer $(\mathrm{pH} \mathrm{5)}$ at temperatures varying from 20 to $100{ }^{\circ} \mathrm{C}$ (Fig. 6a). Up to $75{ }^{\circ} \mathrm{C}$, the phycocyanin was

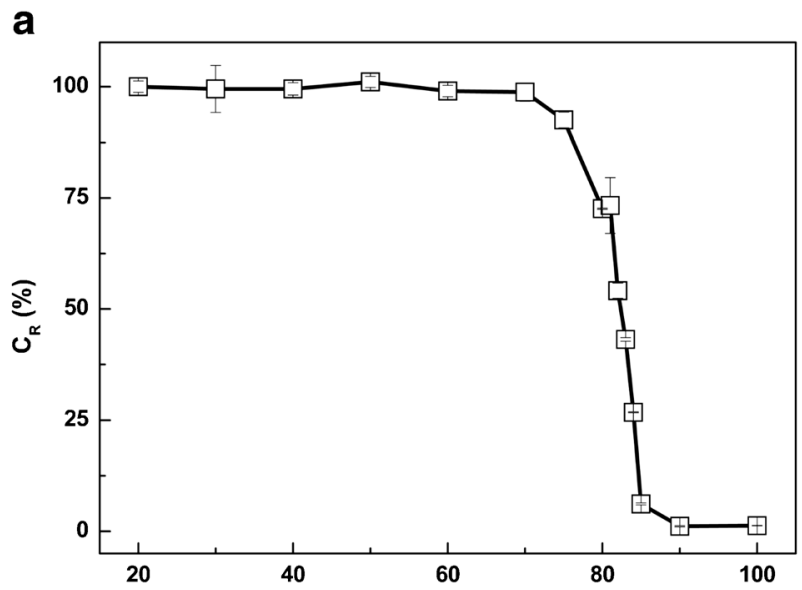

b

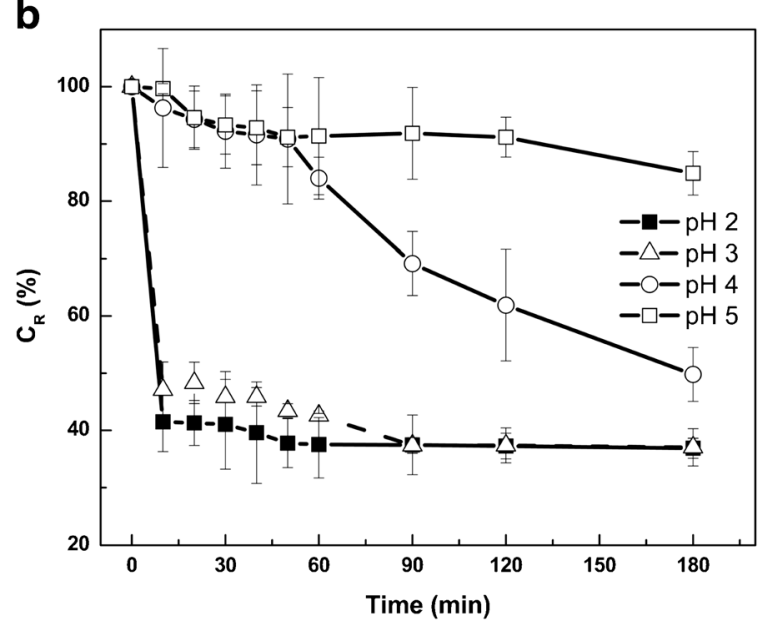

Fig. 6 Characteristics of phycocyanin from C. merolae. a Effect of increasing temperatures on the solubility $\left(C_{\mathrm{R}}(\%)\right)$ of phycocyanin (incubation time: $30 \mathrm{~min}$ ). b pH stability over a period of $180 \mathrm{~min}$ at

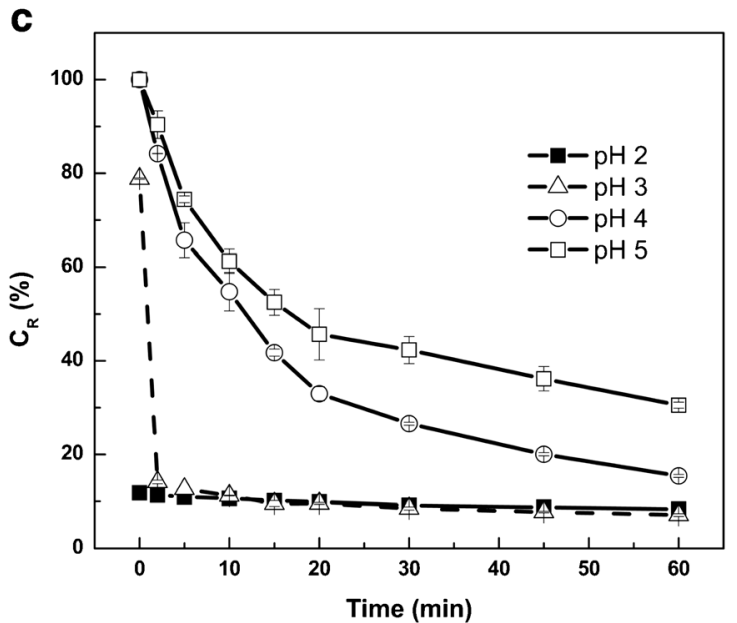

$27^{\circ} \mathrm{C}$ and $\mathbf{c}$ at $80^{\circ} \mathrm{C}$. Black squares $\mathrm{pH} 2$, Triangles $\mathrm{pH} 3$, white circles $\mathrm{pH} 4$, White squares $\mathrm{pH} 5$ 
soluble and remained clearly blue; at temperatures above $75^{\circ} \mathrm{C}$, it started to precipitate and at $90^{\circ} \mathrm{C}$, it had completely precipitated. The denaturation midpoint, which can be defined as that temperature $\left(T_{\mathrm{m}}\right)$ at which $50 \%$ of the phycocyanin is still in solution $\left(C_{\mathrm{R}}=50 \%\right)$, of $C$. merolae phycocyanin is at $83{ }^{\circ} \mathrm{C}$ (Fig. 6a). At room temperature and $\mathrm{pH}$ 5, the $40 \%$ ammonium sulfate purified phycocyanin fraction was stable; more than $85 \%$ stayed in solution for $180 \mathrm{~min}$ (Fig. 6b). At pH 4 , this fraction was already less stable; about $50 \%$ of the phycocyanin was lost after $180 \mathrm{~min}$ of incubation (Fig. 6b). At $80{ }^{\circ} \mathrm{C}$ and $\mathrm{pH}$ of 4 or 5 , the color faded much more rapidly (Fig. 6c). At pH of 2 and 3, the blue color disappeared within several minutes both at room temperature and at $80{ }^{\circ} \mathrm{C}$ (Fig. 6b, c). The half-life of the $40 \%$ ammonium sulfate purified phycocyanin at room temperature was several hundred minutes at $\mathrm{pH} 4$ and 5 while at $\mathrm{pH} 2$ and 3, the phycocyanin faded to colorless in less than $5 \mathrm{~min}$ (Table 2). At high temperature of $80{ }^{\circ} \mathrm{C}$, the phycocyanin had a half-life of 29 to $40 \mathrm{~min}$ at $\mathrm{pH} 4$ and 5, respectively. At pH 2 and 3 and $80^{\circ} \mathrm{C}$, the phycocyanin lost its color within several minutes (Table 2).

Phycocyanin predominantly exists as a hexamer at $\mathrm{pH} 5$, and it is believed that the hexameric form gives some protection against denaturation (Edwards et al. 1996). At pH 7, it is predominantly in a monomeric or trimeric form, resulting in lower thermostability (Edwards et al. 1997; Jespersen et al. 2005). Very likely, the C. merolae phycocyanin is also present in monomeric or trimeric form at low $\mathrm{pH}$, as it looses its thermostability rapidly at these low $\mathrm{pH}$ values. The stability of the $C$. merolae phycocyanin at higher temperatures and a $\mathrm{pH}$ of 4 or 5 is much better than that of the S. platensis phycocyanin. The $T_{\mathrm{m}}$ of the A. platensis phycocyanin is between 55 and $62{ }^{\circ} \mathrm{C}$ (Jespersen et al. 2005; Martelli et al. 2014). The C. merolae phycocyanin protein sequence contains four cysteine residues, whereas the A. platensis phycocyanin sequence, being $75 \%$ identical to the C. merolae sequence, has two cysteine residues (UniProtKB-P72509). Cysteine can form covalent disulfide bonds that contribute to the thermostability of a protein (Fass 2012). Adding high amounts of sugars (40 to 55\%) such as fructose or glucose improved the thermostability of $A$. platensis phycocyanin, indicating that it could be used in high sugar food products such as confectionary and pastries (Martelli et al. 2014). As C. merolae phycocyanin already has a higher thermostability of its own, it could be used in low sugar products that are exposed to higher temperatures during production.

\section{Conclusions}

Phycocyanin can easily be extracted from autotrophically grown $C$. merolae cells by an osmotic shock procedure with ultrapure water. The phycocyanin obtained in this way has a high purity number (9.9) and is thermostable up to $83{ }^{\circ} \mathrm{C}$ at neutral and slight acidic $\mathrm{pH}$. These properties make the $C$. merolae phycocyanin an interesting alternative to A. platensis phycocyanin as a natural blue food colorant.

Acknowledgements DYR was supported by the Ubbo Emmius PhD scholarship program of the University of Groningen.

Open Access This article is distributed under the terms of the Creative Commons Attribution 4.0 International License (http:// creativecommons.org/licenses/by/4.0/), which permits unrestricted use, distribution, and reproduction in any medium, provided you give appropriate credit to the original author(s) and the source, provide a link to the Creative Commons license, and indicate if changes were made.

\section{References}

Albertano P, Ciniglia C, Pinto G, Pollio A (2000) The taxonomic position of Cyanidium, Cyanidioschyzon and Galdieria: an update. Hydrobiologia 433:137-143

Allen MB (1959) Studies with Cyanidium caldarium, an anomalously pigmented chlorophyte. Arch Mikrobiol 32:270-277

Antello FS, Costa JAV, Kal SJ (2008) Thermal degradation kinetics of the phycocyanin from Spirulina platensis. Biochem Eng 41:43-47

Arnold LE, Lofthouse N, Hurt E (2012) Artificial food colors and attention-deficit/hyperactivity symptoms: conclusion to dye for. Neurotherapeutics 9:599-609

Belay A (2013) Biology and industrial production of Arthrospira (Spirulina). In: Richmond A, Hu Q (eds) Handbook of microalgal culture: applied phycology and biotechnology. Blackwell, Oxford, pp. 339-358

Bennett A, Bogorad L (1973) Complementary chromatic adaptation in a filamentous blue-green alga. J Cell Biol 58:419-435

Biggins J, Bruce D (1989) Regulation of excitation energy transfer in organism containing phycobilins. Photosynth Res 20:1-34

Chaiklahan R, Chirasuwan N, Loha V, Tia S, Bunnag B (2011) Separation and purification of phycocyanin from Spirulina sp. using a membrane process. Bioresource Technol 102:7159-7164

Ciniglia C, Yoon HS, Pollio A, Pinto G, Bhayyacharya D (2004) Hidden biodiversity of the extremophilic Cyanidiales red algae. Mol Ecol 13:1827-1838

Cisneros M, Rito-Palomares M (2004) A simplified strategy for the release and pimary recovery of C-phycocyanin produced by Spirulina platensis. Chem Biochem Eng Q 18:385-390

Code of Federal Regulation (2016) Spirulina extract. https://www. govregs.com/regulations/title21_chapterI_part73_subpartA_ section 73.530, accessed 13 July 2016

Coyler CL, Kinkade CS, Viskari PJ, Landers JP (2005) Analysis of cyanobacterial pigment and proteins by electrophoretic and chromatographic method. Anal Biochem Chem 382:559-569

Edwards MR, MacColl R, Eisele LE (1996) Some physical properties of an usual C-phycocyanin isolated from a photosynthethic thermopile. Biochem Biophys Acta 1276:64-70

Edwards MR, Houer C, Stack RF, Eisele LE, MacColl R (1997) Thermophilic C-phycocyanin: effect of temperature, monomer stability, and structure. Biochem Biophys Acta 1321:157-164

Eriksen NT (2008) Production of phycocyanin — a pigment with application in biology, biotechnology, foods, and medicine. Appl Microbial Biotechnol 80:1-14

Jespersen L, Strømdahl LD, Olsen K, Skibsted LH (2005) Heat and light stability of natural blue colorants for use in confectionery and beverages. Eur Food Res Technol 220:261-266 
Fass D (2012) Disulfide bonding in protein biophysics. Annu Rev Biophys 41:63-79

Giltelson AA, Buschmann C, Lichtenthaler HK (1999) The chlorophyll fluorescen ratio $\mathrm{F}_{735} / \mathrm{F}_{700}$ as an accurate measure of the chlorophyll content in plants. Remote Sens Environ 69:296-302

Glazer AN (1989) The light guide: directional energy transfer in a photosynthetic antenna. J. Biol Chem 264:1-4

Glazer AN, Fang S (1996) Chromophore content of blue-green algal phycobiliproteins. J Biol Chem 248:659-662

Gross W, Schnarrenberger C (1995) Heterotrophic growth of two strains of the acidophilic red algae Galdieria sulphuraria. Plant Cell Physiol 36:633-638

Gupta A, Sainis JK (2010) Isolation of C-phycocyanin from Synechococcus sp. (Anacystis nidulans BD1). J Appl Phycol 22: 231-233

Lee YK (1997) Commercial production of microalga in Asia-Pacific rim. J Appl Phycol 9:403-411

Lee RE (2004) Phycology, 4th edn. Cambridge University Press, Cambridge, pp. 108-109

Liao X, Zhang B, Wang X, Yan H, Zhang X (2011) Purification of Cphycocyanin from Spirulina platensis by single-step ion-exchange chromatography. Chromatographia 73:291-296

Martelli G, Folli C, Vista L, Daglia M, Ferrari D (2014) Thermal stability improvement of blue colorant C-phycocyanin from Spirulina platensis for food industry application. Process Biochem 49:154159

McCann D, Barret A, Cooper A, Crumpler D, Dalne L, Grimshaw K, Kitchin E, Lok K, Porteous L, Prince E, Sanuga-Barke E, Warnet JO, Stevenson J (2007) Food additives and hyperactive in 3-year-old and 8/9-year-old children in the community: a randomized, doubleblinded, placebo-controlled trial. Lancet 370:1560-1567

Newsome AG, Culter CA, van Breemen RB (2014) Nature's palette: the search for natural blue colorants. J Agric Food Chem 62:6498-6511

Niu JF, Wang GC, Lin X, Zhou BC (2007) Large-scale recovery of phycocyanin from Spirulina platensis using expanded bed adsorption chromatography. J Chromatogr B 850:267-276
Padyana AK, Bhat VB, Madyastha KM, Rajashankar KB, Ramakumar S (2001) Crystal structure of light-harvesting protein C-phycocyanin from Spirulina platensis. Biochem Biophys Res Commun 282:893898

Patel A, Mishra S, Pawar R, Ghosh PK (2005) Purification and characterization of phycocyanin from cyanobacterial species of marine and freshwater habitat. Prot Expr Pur 40:248-255

Richmond A, Grobbelaar JU (1986) Factor affecting the output rate of Spirulina platensis with reference to mass cultivation. Biomass 10: 253-264

Rito-Palomares M, Nunez L, Amadr D (2004) Practical application of aqueous two-phase system for development of a prototype process for c-phycocyanin recovery from Spirulina maxima. J Chem Technol Biotechnol 76:1273-1280

Silveira S, Burkert JFM, Costa JAV, Burkert CAV, Kalil SJ (2007) Optimization of phycocyanin extraction from Spirulina platensis using factorial design. Bioresource Technol 98:1629-1634

Sloth JK, Wiebe MK, Eriksen NT (2006) Accumulation of phycocyanin in heterotrophic and mixotrophic cultures of the acidophilic red algae Galdieria sulphuraria. Enz Microb Technol 38:168-175

Sørensen L, Hantke A, Eriksen NT (2012) Purification of the photosynthetic pigment C-phycocyanin from heterotrophic Galdieria sulphuraria. J Sci Food Agric 93:2933-2938

Stec B, Troxler RF, Teeter MM (1999) Crystal structure of Cphycocyanin from Cyanidium caldarium provides a new perspective on phycobilisomes assembly. Biophys J 76:2912-2921

Wrolstad RE, Culter CA (2012) Alternatives to those artificial FD and C food colorant. Annu Rev Food Sci Technol 3:59-77

Yan S, Zhu L, Su H, Zhang X, Chen X, Zhou B, Zhang Y (2011) Single step chromatography for simultaneous purification of Cphycocyanin and allophycocyanin with high purity and recovery from Spirulina (Arthrospira) platensis. J Appl Phycol 3:1-6

Zhang Y, Chen F (1999) A simple method for efficient separation and purification of C-phycocyanin and allophycocyanin from Spirulina platensis. Biotechnol Technol 13:601-603 